\title{
Do children with mental disorders have higher prevalence of
}

\section{hypovitaminosis D? [version 1; peer review: 1 approved, 2}

\section{approved with reservations]}

\author{
Mini Zhang ${ }^{1}$, Keith Cheng ${ }^{1}$, Robert Rope ${ }^{2}$, Elizabeth Martin ${ }^{3}$, Ajit Jetmalani ${ }^{1}$ \\ ${ }^{1}$ Department of Psychiatry, Oregon Health and Science University, Portland OR, 97239, USA \\ ${ }^{2}$ Department of Internal Medicine, Oregon Health and Science University, Portland OR, 97239, USA \\ ${ }^{3}$ School of Medicine, Oregon Health and Science University, Portland OR, 97239, USA
}

V1 First published: 17 Jul 2013, 2:159

https://doi.org/10.12688/f1000research.2-159.v1

Latest published: 17 Jul 2013, 2:159

https://doi.org/10.12688/f1000research.2-159.v1

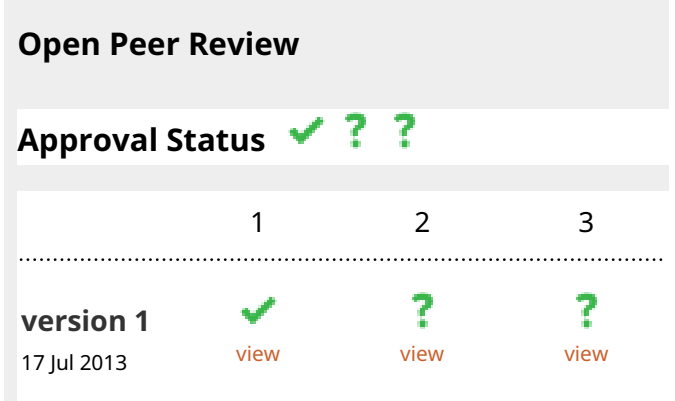

1. Shailesh Jain, Texas Tech University, Lubbock TX, USA

2. Linda Mayes, Yale University, New Haven CT, USA

3. Hans-Peter Volz, Hospital for Psychiatry, Psychotherapy and Psychosomatic Medicine Schloss Werneck, Bavaria, Germany Any reports and responses or comments on the article can be found at the end of the article. 
Keywords

Vitamin D, mental illness, psychoses, autism, mood, insufficiency,

deficiency, 25(OH)D, paediatric

Corresponding author: Mini Zhang (zhangmini07@gmail.com)

Competing interests: No competing interests were disclosed.

Grant information: The author(s) declared that no grants were involved in supporting this work.

Copyright: (c) 2013 Zhang M et al. This is an open access article distributed under the terms of the Creative Commons Attribution License , which permits unrestricted use, distribution, and reproduction in any medium, provided the original work is properly cited. Data associated with the article are available under the terms of the Creative Commons Zero "No rights reserved" data waiver (CC0 1.0 Public domain dedication).

How to cite this article: Zhang M, Cheng K, Rope R et al. Do children with mental disorders have higher prevalence of hypovitaminosis D? [version 1; peer review: 1 approved, 2 approved with reservations] F1000Research 2013, 2:159 https://doi.org/10.12688/f1000research.2-159.v1

First published: $17 \mathrm{Jul}$ 2013, 2:159 https://doi.org/10.12688/f1000research.2-159.v1 


\section{Introduction}

An inadequate vitamin $\mathrm{D}$ level is increasingly being linked to diverse disease states. Beyond its importance in endocrine and bone health, there is a growing concern that vitamin $\mathrm{D}$ insufficiency may affect brain function and mental health.

Studies have linked hypovitaminosis D to various psychiatric disorders such as depressed $\operatorname{mood}^{1}$ and schizophrenia ${ }^{2,3}$. In children, emerging evidence suggests that vitamin D plays a role in brain development ${ }^{4-6}$. A Finnish study found that vitamin $\mathrm{D}$ supplementation in infancy reduced the risk of schizophrenia later in life among males ${ }^{7}$. A Swedish study found that patients diagnosed with schizophrenia and autism had the lowest 25-hydroxyvitamin D (25(OH)D) levels among psychiatric diagnoses, and proposed that low $25(\mathrm{OH}) \mathrm{D}$ may not only be a predisposing developmental factor, but may also affect mental health in adulthood ${ }^{3}$. Therefore, prevention of hypovitaminosis $\mathrm{D}$ in early life may be associated with reduced risk of developing certain psychiatric disorders.

The optimal level of vitamin $\mathrm{D}$ is controversial. The cutoff serum levels range from 20 to $50 \mathrm{ng} / \mathrm{ml}^{8}$. The American Academy of Pediatrics (AAP) recommends a minimal level of $20 \mathrm{ng} / \mathrm{ml}$ in children. Using the same cut-off value, the US Institute of Medicine (IOM) reports that the majority of North Americans have sufficient vitamin $\mathrm{D}$ required for bone health ${ }^{8}$. However, some subgroups, particularly those who are older, those living in institutions, or those with darker skin, may be at increased risk for hypovitaminosis $\mathrm{D}^{8}$.

Vitamin D insufficiency in the general population was estimated to range from $1 \%$ to $78 \%$ among different studies 9 . Using the Third National Health and Nutrient Examination Survey (NHANES III, 1988-94) data, Saintonge et al. estimated that $14 \%$ of healthy children had 25(OH)D levels below $20 \mathrm{ng} / \mathrm{ml}$, and $48 \%$ had levels below $30 \mathrm{ng} / \mathrm{ml}^{10}$. The prevalence of hypovitaminosis $\mathrm{D}$ among children with mental disorders remains unclear.

This study attempts to ascertain whether children with mental illness have a higher prevalence of hypovitaminosis $\mathrm{D}$ and whether there is a difference in prevalence across various disorders.

\section{Methods}

A retrospective chart review was conducted at two residential psychiatric treatment programs in Oregon, USA, (latitude $\left.45^{\circ} \mathrm{N}\right)$. There were 67 patients aged from 7 to 17 years, whose serum 25(OH)D levels were measured between October 2009 and 2010. Patients had one to four co-morbid psychiatric diagnoses. There were no exclusion criteria. Given the retrospective nature and lack of identifiable health data used in the study, no institutional review board approval was needed.
Deficiency was defined as $<20 \mathrm{ng} / \mathrm{ml}$, based on the AAP recommended value. Insufficiency was defined as $<30 \mathrm{ng} /$ $\mathrm{ml}$, by the local laboratory standard used in Oregon. For the 14 patients who had multiple $25(\mathrm{OH}) \mathrm{D}$ levels recorded, we used the lowest $25(\mathrm{OH}) \mathrm{D}$ level in our analyses. We felt this method was justified clinically if any period with this degree of hypovitaminosis D during childhood is correlated to developmental differences. The diagnoses were organized into six categories shown in Table 1. For patients with multiple diagnoses, their $25(\mathrm{OH}) \mathrm{D}$ level was counted individually in each diagnostic category to calculate the mean and prevalence.

$25(\mathrm{OH}) \mathrm{D}$ levels were compared across genders and diagnostic groups using a two-sample t-test and ANOVA, respectively. Statistical differences in prevalence across diagnostic groups were calculated using a Pearson chi-square test. The analysis was performed using STATA IC (version 11) from StataCorp LP, College Station, Texas.

\section{Results}

A total of 67 patients with 168 diagnoses were included in this study. Using the NHANES III study ${ }^{10}$ for comparison, $21 \%$ of our cohort were vitamin D deficient $(<20 \mathrm{ng} / \mathrm{ml})$, compared to $14 \%$ reported in the general US population. If a cut-off value of $30 \mathrm{ng} / \mathrm{ml}$ was used, $64 \%$ of the children in our study population were classified as being insufficient, compared to $48 \%$ of healthy US children.

The overall mean $25(\mathrm{OH}) \mathrm{D}$ level in our study cohort was $27.59 \pm 9.35 \mathrm{ng} / \mathrm{ml}$ (i.e. insufficient), compared to a mean value of $32.1 \mathrm{ng} / \mathrm{ml}$ (i.e. sufficient) in the general US population $^{10}$. Females in our study $(n=29)$ had a mean level of 27.4 $\pm 9.1 \mathrm{ng} / \mathrm{ml}$, comparable to the mean of $27.74 \pm 9.66 \mathrm{ng} / \mathrm{ml}$ amongst males $(n=38)$. The gender difference was non-significant $(\mathrm{p}=0.89)$. The mean $25(\mathrm{OH}) \mathrm{D}$ levels by diagnostic category are shown in Table 2 . No statistical significant differences could be concluded in the mean level $(\mathrm{p}=0.80)$ across diagnostic categories.

The prevalence of patients with hypovitaminosis D across diagnostic groups using both cutoff values are shown in Figure 1. There was no statistical significance found in the prevalence across diagnostic groups, perhaps due to the small sample size. It is interesting to note that psychotic disorder had the highest prevalence of deficiency and insufficiency among specific diagnostic groups: $43 \%$ and $71 \%$, respectively.

Vitamin D levels in a pediatric population with mental disorders at two residential psychiatric treatment programs in Oregon

2 Data Files

http://dx.doi.org/10.6084/m9.figshare.732736 
Table 1. Diagnostic categories.

\begin{tabular}{|c|c|}
\hline Category & Diagnoses included \\
\hline Anxiety disorder & $\begin{array}{l}\text { - Anxiety Post traumatic stress disorder } \\
\text { - Obsessive compulsive disorder } \\
\text { - Post traumatic stress disorder }\end{array}$ \\
\hline Autism spectrum disorders (ASD) & $\begin{array}{l}\text { - Autism } \\
\text { - Asperger's syndrome } \\
\text { - Pervasive developmental disorder }\end{array}$ \\
\hline Disruptive disorders & $\begin{array}{l}\text { - Attention deficit/hyperactive disorder (ADD/ADHD) } \\
\text { - Conduct disorder } \\
\text { - Disruptive disorder not otherwise specified (NOS) } \\
\text { - Optermittent explosive disorder } \\
\text { - Oppositional defiant disorder }\end{array}$ \\
\hline Mood disorders & $\begin{array}{l}\text { - Bipolar disorder I and II } \\
\text { - Cyclothymia } \\
\text { - Major depression }\end{array}$ \\
\hline Psychotic disorders & $\begin{array}{l}\text { - Psychotic disorder NOS } \\
\text { - Schizoaffective disorder } \\
\text { - Schizophrenia }\end{array}$ \\
\hline Other disorders & $\begin{array}{l}\text { - Acculturation problem } \\
\text { - } \text { Eognitive disorder } \\
\text { - Eating disorder } \\
\text { - Enuresis } \\
\text { - Language/communication disorder } \\
\text { - Learning disorder } \\
\text { - Relational problem } \\
\text { - Sleep disorder } \\
\text { - Substance abuse and dependence }\end{array}$ \\
\hline
\end{tabular}

\section{Table 2. Percent and mean 25(OH)D level by diagnostic} categories.

\begin{tabular}{|llll|}
\hline Category & $\begin{array}{l}\text { Percent of } \\
\text { study cohort } \\
(\mathbf{n = 1 6 8})\end{array}$ & $\begin{array}{l}\text { Mean 25(OHD) } \\
\text { level }\end{array}$ & $\begin{array}{l}\text { Std. dev } \\
\text { (ng/ml) }\end{array}$ \\
\hline Anxiety disorder & $18 \%(n=30)$ & 27.89 & 10.58 \\
\hline $\begin{array}{l}\text { Autism spectrum } \\
\text { disorders (ASD) }\end{array}$ & $9 \%(n=15)$ & 29.72 & 11.58 \\
\hline Disruptive disorders & $27 \%(n=46)$ & 27.27 & 6.74 \\
\hline Mood disorders & $27 \%(n=45)$ & 28.96 & 10.11 \\
\hline Psychotic disorders & $4 \%(n=7)$ & 26.47 & 12.42 \\
\hline Other disorders & $15 \%(n=25)$ & 26.02 & 10.85 \\
\hline
\end{tabular}

\section{Discussion}

Beyond its importance in endocrine function, there is growing awareness of the role that vitamin D plays in brain function. However, the prevalence of hypovitaminosis D in children with mental illnesses is uncertain. This study found that children with serious psychiatric disorders may have a higher prevalence of hypovitaminosis $\mathrm{D}$ and a lower mean $25(\mathrm{OH}) \mathrm{D}$ level, compared to the general US population ${ }^{10}$. Although no statistical significance can be concluded, it is noteworthy that psychotic disorders had the highest preva- lence of hypovitaminosis D among the specific diagnostic categories, which supports previous studies ${ }^{2,3,7}$. We suggest using a cut-off value of $20 \mathrm{ng} / \mathrm{ml}$ for clinical interventions, as recommended by the AAP and $\mathrm{IOM}^{10}$. Clinicians should discuss the costs and benefits of treatment with patients when levels are between 20 and $30 \mathrm{ng} / \mathrm{ml}$.

The primary limitation of this study was its small sample size. Due to its retrospective design, we were limited by the availability of $25(\mathrm{OH}) \mathrm{D}$ studies without specific clinical indications. Other limitations include not controlling for the length of inpatient stay, ethnicity, age, nutritional status, sun exposure, or skin pigmentation. For the patients with multiple diagnoses, their $25(\mathrm{OH}) \mathrm{D}$ was counted in each diagnostic category, which might overestimate the prevalence of hypovitaminosis D. The study utilized the lowest level of $25(\mathrm{OH}) \mathrm{D}$ for patients with multiple measurements, which might result in lower mean level and higher prevalence. Although a causal relationship between hypovitaminosis $\mathrm{D}$ and psychiatric disorders cannot be derived based on the study design, our study provides important initial descriptive data on the prevalence of hypovitaminosis $\mathrm{D}$ in a pediatric population with psychiatric disorders which has not, to our knowledge, been previously reported. 


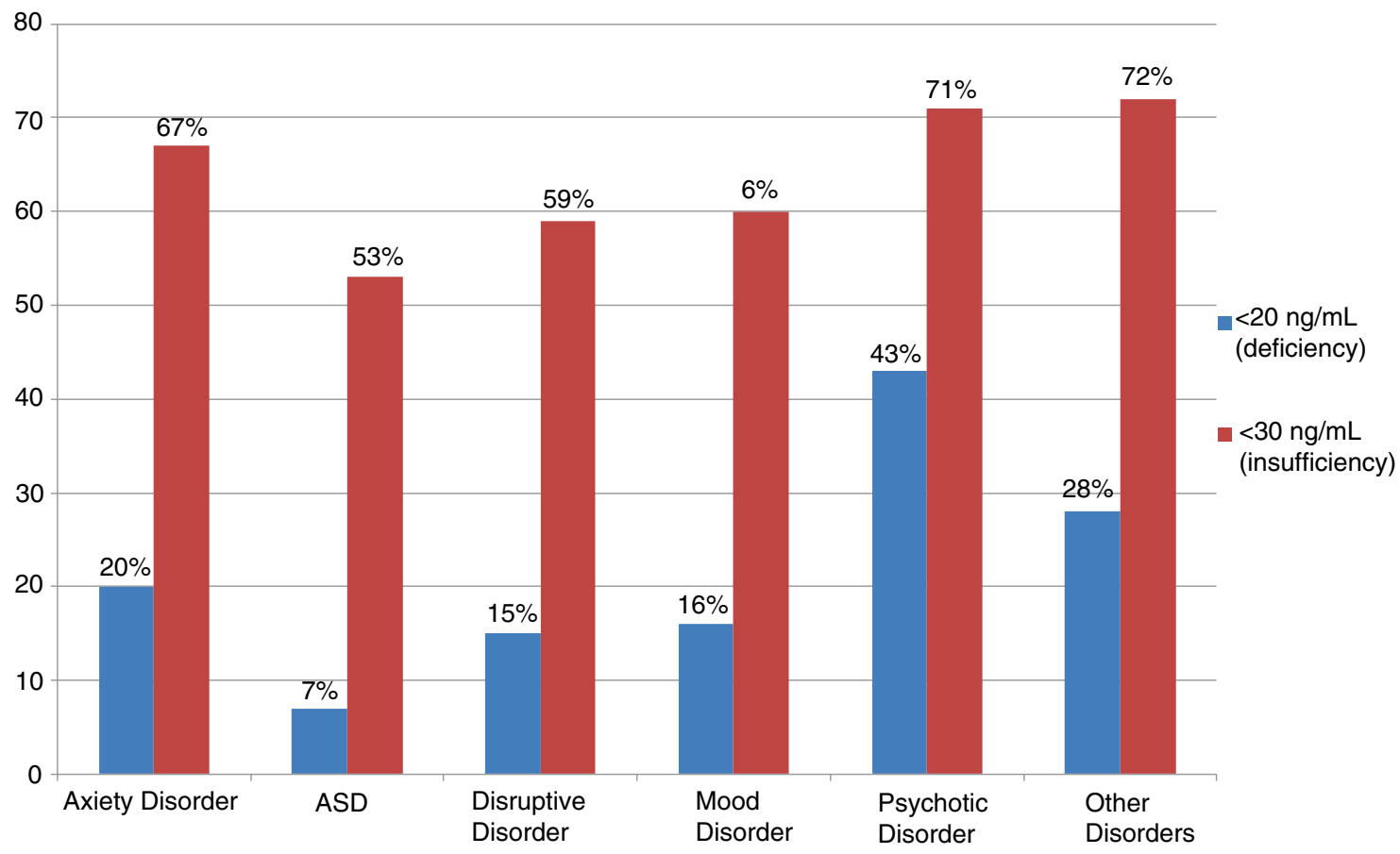

Figure 1. Prevalence of 25(OH)D deficiency $(p=0.28)$ and insufficiency $(p=0.72)$ across diagnostic categories in a pediatric population with mental disorders. See Table 1 for a list of 'Other Disorders'.

\section{Conclusion}

As research continues on the impact of vitamin $\mathrm{D}$ in medicine, its implication for psychiatric disorders may be clarified. While no robust statistical conclusions can be made mainly due to small sample size, this study provides initial data suggesting that children with mental illnesses might have lower vitamin D levels and a higher prevalence of hypovitaminosis D than the general population.

Given the high prevalence of hypovitaminosis $\mathrm{D}$ and its profound impact on overall health, clinicians should have a higher suspicion of hypovitaminosis $\mathrm{D}$ in the pediatric psychiatric population.

Important future steps include the design of a larger prospective study with more controlled variables would allow more precise analysis to establish the prevalence of hypovitaminosis $\mathrm{D}$, as well as to infer any correlation between hypovitaminosis $\mathrm{D}$ and childhood mental illness. Preventative and ameliorative measures might subsequently be instigated to assess causation and affect the development and treatment of certain mental disorders.

\section{Author contributions}

MZ and KC conceived the study. MZ designed the study, compiled the data, and prepared the first and final drafts of the manuscript. KC provided the data source, provided expert guidance, revised the manuscripts, and oversaw the study. RR contributed to the study design and manuscript preparation. EM provided statistical analysis of the data and contributed to revision of the manuscript. AJ provided revisions of the manuscript. All authors were involved in the revision of the draft manuscript and have agreed to the final content.

\section{Competing interests}

No competing interests were disclosed.

\section{Grant information}

The author(s) declare that no grants were involved in supporting this work.

\section{Acknowledgements}

Special thanks to Dr. Eric Turner for guidance in the submission and publication process. 
1. Ganji V, Milone C, Cody MM, et al: Serum vitamin D concentrations are related to depression in young adult US population: the Third National Health and Nutrition Examination Survey. Int Arch Med. 2010; 3: 29

2. McGrath JJ, Eyles DW, Pedersen CB, et al: Neonatal vitamin D status and risk of schizophrenia: a population-based case-control study. Arch Gen Psychiatry. 2010; 67: 889-94.

3. Humble MB, Gustafsson S, Bejerot S: Low serum levels of 25-hydroxyvitamin D (25-OHD) among psychiatric out-patients in Sweden: Relations with season, age, ethnic origin and psychiatric diagnosis. J Steroid Biochem Mol Biol. 2010; 121: 467-70.

4. Eyles D, Burne T, McGrath J: Vitamin D in fetal brain development Semin Cell Dev Biol. 2011; 22: 629-36.

5. Kesby JP, Eyles DW, Burne TH, et al: The effects of vitamin D on brain development and adult brain function. Mol Cell Endocrinol. 2011; 347: 121-7.

6. Grant WB, Soles CM: Epidemiologic evidence supporting the role of maternal vitamin $D$ deficiency as a risk factor for the development of infantile autism. Dermatoendocrinol. 2009; 1 223-8.

7. McGrath J, Saari K, Hakko H, et al: Vitamin D supplementation during the first year of life and risk of schizophrenia: a Finnish birth cohort study. Schizophr Res. 2004: 67: 237-45.

8. Institute of Medicine of the National Academies. Implications and Special Concerns. In A. Catharine Ross, Christine L. Taylor, Ann L. Yaktine, and Heather B. Del Valle, ed. DRI Dietary Reference Intakes for Calcium Vitamin D. 1st ed. Washington, DC: National Academies Press, 2011: 487.

9. Rovner AJ, O'Brien KO: Hypovitaminosis D among healthy children in the United States: a review of the current evidence. Arch Pediatr Adolesc Med. 2008; 162: 513-9.

10. Saintonge $S$, Bang $H$, Gerber LM: Implications of a new definition of vitamin $D$ deficiency in a multiracial US adolescent population: the National Health and Nutrition Examination Survey III Pediatrics. 2009; 123: 797803 


\section{Open Peer Review}

\section{Current Peer Review Status: $\checkmark$ ? ?}

\section{Version 1}

Reviewer Report 31 July 2013

https://doi.org/10.5256/f1000research.1765.r1112

(C) 2013 Volz H. This is an open access peer review report distributed under the terms of the Creative Commons Attribution License, which permits unrestricted use, distribution, and reproduction in any medium, provided the original work is properly cited.

\section{Hans-Peter Volz}

School for Psychiatry and Psychotherapy, Hospital for Psychiatry, Psychotherapy and Psychosomatic Medicine Schloss Werneck, Bavaria, Germany

The authors should clearly state whether they included all patients of this age group or whether the included patients represent a sub-sample; if yes, according to which inclusion criteria?

Since patients with multiple diagnoses have been counted in each diagnostic category they fulfilled, a second analysis would be helpful in which every patient is counted only once.

Was there any medication given that could influence vitamin D-Levels?

If the authors can meet these points of criticism, the paper is well suited to be approved

Competing Interests: No competing interests were disclosed.

I confirm that I have read this submission and believe that I have an appropriate level of expertise to confirm that it is of an acceptable scientific standard, however I have significant reservations, as outlined above.

Reviewer Report 25 July 2013

https://doi.org/10.5256/f1000research.1765.r1117

(C) 2013 Mayes L. This is an open access peer review report distributed under the terms of the Creative Commons Attribution License, which permits unrestricted use, distribution, and reproduction in any medium, provided the original work is properly cited. 


\begin{abstract}
Linda Mayes
Yale University, New Haven CT, USA

While the report offers an interesting hypothesis, the sample is under-powered and the findings are not significant. There are also many biases in why vitamin D levels were or were not measured in psychiatric samples. The authors note limitation of sample size. I would suggest increasing sample size and being more targeted in the definition of psychopathology in future case control design.

Competing Interests: No competing interests were disclosed.

\section{I confirm that I have read this submission and believe that I have an appropriate level of expertise to confirm that it is of an acceptable scientific standard, however I have significant reservations, as outlined above.}

Author Response 29 Jul 2013

Mini Zhang, Oregon Health and Science University, Portland OR, USA

Dear Dr. Mayes,

Thank you for your comments and suggestions. We are aware of several limitations of our study including the sample size and the method of vitamin D measurement, as we stated in our paper. We agree that a bigger sample size and better design with controlled variables, and a prospective study will significantly increase the power and validity of our study. This study is the initial step, and we hope we would be able to pursue this a step further in the future.

Thank you again for your time and expert opinion.

Regards,

Mini Zhang, MD

Competing Interests: No competing interests were disclosed.

Reviewer Report 23 July 2013

https://doi.org/10.5256/f1000research.1765.r1188

(C) 2013 Jain S. This is an open access peer review report distributed under the terms of the Creative Commons Attribution License, which permits unrestricted use, distribution, and reproduction in any medium, provided the original work is properly cited.

\title{
Shailesh Jain
}




\section{Texas Tech University, Lubbock TX, USA}

The title of the article is appropriate to the content of the article.

The abstract is able to summarize the key elements of the research including the brief overview of the study design, statistical methods used and the key conclusion.

The article is well constructed and clear in its presentation. It is succinct, direct, to the point and conveys clear message.

Study design has been conducted, properly measured and collected appropriately. Due diligence has been made as pointed out regarding privacy of the patients. The ethnicity of IRB involvement is also clearly pointed out.

The study design and methodology has been clearly delineated. The methodology and the steps described in this study can easily be replicated in future studies.

The data are presented in an easy to understand and informative way which a busy reader can easily grasp the key findings.

The study presentation has included all the data that are necessary to understand the key findings and helpful for future studies.

Limitations are adequately described though the fact that other possible explanations, such as medical conditions, are not taken into account.

Though the data 'look' okay, I would recommend a review by a statistician.

Competing Interests: No competing interests were disclosed.

\section{I confirm that I have read this submission and believe that I have an appropriate level of expertise to confirm that it is of an acceptable scientific standard.}

\section{Author Response 25 Jul 2013}

Mini Zhang, Oregon Health and Science University, Portland OR, USA

Dear Dr. Jain,

Thank you very much for your nice words and comments! We appreciate your time and expertise in reviewing our article.

Please feel free to contact me if you have further comments or questions.

Sincerely,

Mini Zhang, MD 
Competing Interests: No competing interests were disclosed.

The benefits of publishing with F1000Research:

- Your article is published within days, with no editorial bias

- You can publish traditional articles, null/negative results, case reports, data notes and more

- The peer review process is transparent and collaborative

- Your article is indexed in PubMed after passing peer review

- Dedicated customer support at every stage

For pre-submission enquiries, contact research@f1000.com 